\title{
Effects of Dietary Zinc Deficiency on Protein Secretory Functions of the Mouse Testis*
}

\author{
Hiroshi Ueda ${ }^{1 * *}$, Fujio KAYAMA ${ }^{2}$, Naoki Mori ${ }^{1}$, Yoshiaki DoI ${ }^{1}$ and Sunao FuJimoto ${ }^{1}$ \\ Department of Anatomy ${ }^{1}$ and Department of Environmental Health ${ }^{2}$, School of Medicine, University of Occupational and \\ Environmental Health, Kitakyushu, Japan
}

Received April 18, 1991

\begin{abstract}
Summary. The effects of dietary zinc deficiency on testicular protein secretion, mainly that by Sertoli cells, were examined by electron microscopy and twodimensional polyacrylamide gel electrophoresis of $\left[{ }^{35} \mathbf{S}\right]$ methionine-labeled secretory proteins from mouse testes.

Zinc deficiency caused a significant decrease in the gonadosomatic index and a distinct increase in deoxyribonucleic acid concentration. Sertoli cells maintained normal fine-structural features; junctional complexes among Sertoli cells continued to divide seminiferous tubules into basal and adluminal compartments in the zinc-deficient mouse testes. Severe atrophic changes were observed in spermatogenic cells after meiotic division in the adluminal compartment, but not in spermatogonia located in the basal compartment. Zinc replacement treatment caused spermatogenesis to recover normally.

Although total protein secretion was not affected by zinc deficiency, one polypeptide spot appeared due mainly to the loss of its target spermatogenic cells. The present study indicates that zinc is indispensable for spermatogenic cells after meiosis and that testicular protein secretory functions can be preserved in the absence of zinc.
\end{abstract}

It is well-known that zinc is an essential trace element which plays an important role in many biological functions (GoRDON et al., 1981). Zinc performs critical roles in the physiological functions of many metalloenzymes, especially in the synthesis of ribonucleic acid (RNA) and deoxyribonucleic acid (DNA)
(Prasad and Oberleas, 1974; Chesters, 1978).

In the testes of laboratory and domestic animals, zinc deficiency has been known to inhibit testicular development (FOLlIS et al., 1941; MiLlaR et al., 1958, Miller et al., 1964; PITTS et al., 1966; PRASAD et al., 1967), cause abnormal spermiogenesis (ORGEBINCRIST et al., 1971; DinSDAle and Williams, 1980), affect Leydig cell functions and the pituitary-gonadal axis (LEI et al., 1976; HESKETH, 1982), and decrease the calmodulin content of the testes (LAW et al., 1987). Notwithstanding these various studies, no zinc deficiency experiments seem to have been performed with regard to the protein secretory functions of the testis.

Among the somatic cells (Sertoli, Leydig, and peritubular cells) and spermatogenic cells in the testis, Sertoli cells have been considered to assume the most important role in testicular protein secretion. The contribution of Sertoli cell secretory proteins to the whole process of spermatogenesis and spermiogenesis has been intensively studied (KIERSZENBAUM et al., 1987; BARDIN et al., 1988).

The present study was designed to analyse the effects of dietary zinc deficiency on testicular protein secretion by two-dimensional polyacrylamide gel electrophoresis (2D-PAGE) of $\left[{ }^{35} \mathrm{~S}\right]$ methionine-labeled secretory proteins from mouse testes. In addition, ultrastructural observations of the zinc-deficient mouse testes with special attention to Sertoli cells were carried out to correlate these with their protein secretory functions.

\footnotetext{
*This study was supported in part by a Grant-in-Aid for special project research from the Japanese Ministry of Labor.

**Present address: Toya Lake Station for Environmental Biology, Faculty of Fisheries, Hokkaido University, Abuta, Hokkaido, Japan.
} 


\section{MATERIALS AND METHODS}

\section{Animals and treatment}

Nineteen male C3H mice (4 or 5 weeks old) were purchased from Seiwa Experimental Animals (Fukuoka, Japan), and divided into four groups (4 to 5 mice/group). They were housed in plastic cages covered with wooden pens and given only distilled water. Control (C) and pair-fed (P) groups received a zincdefined diet $(58 \mathrm{ppm})$ for 5 weeks. The $\mathrm{P}$ group received the diet in an amount equivalent in weight to that consumed by the zinc-deficient groups ( $\mathrm{ZnD}$ and
$\mathrm{ZnR}$ ). The $\mathrm{ZnD}$ and $\mathrm{ZnR}$ groups received a zincdeficient diet $(0.5 \mathrm{ppm})$ for 5 weeks, and the $\mathrm{ZnR}$ group received the zinc-defined diet for another 3 weeks. These diets were purchased from Nippon Clea (Osaka, Japan); the composition of diet has been previously reported (KAYAMA et al., 1990).

During treatment, there were no gains in body weight in the $\mathrm{P}$ and $\mathrm{ZnD}$ groups, in contrast with the normal gain in the $\mathrm{C}$ and $\mathrm{ZnR}$ groups after the replacement of the zinc-defined diet. At the end of each treatment, relative testicular weight was estimated by the gonadosomatic index (GSI: testicular weight $\times 100$ /body weight). Testicular DNA and

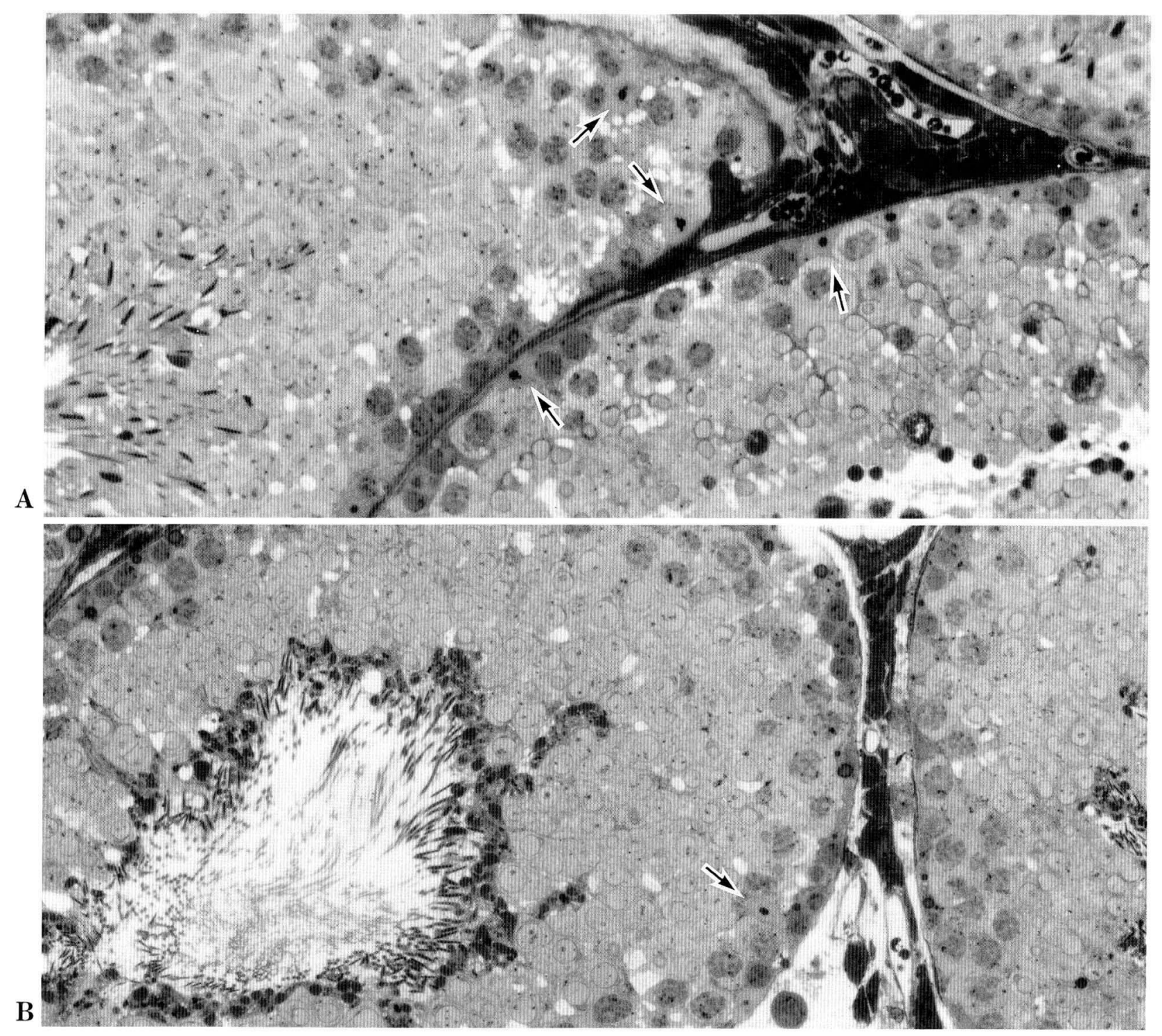

Fig. 1. Thick sections of testes in control (A), pair-fed (B), zinc-deficient (C) and zinc replacement (D) groups. Note atrophic features of the adluminal compartment in the zinc-deficient seminiferous tubules (C). Arrows indicate Sertoli cells. $\times 500$ 
protein concentrations were determined by the methods of SCHNEIDER (1957) and LOWRY et al. (1951), respectively.

\section{Light and electron microscopy}

Small pieces of testes from each group were fixed with $2 \%$ paraformaldehyde- $1 \%$ glutaraldehyde in 0.1 M phosphate buffer (PB; pH 7.2) for $18 \mathrm{~h}$, rinsed with $0.1 \mathrm{M}$ PB containing 10\% sucrose for $2 \mathrm{~h}$, and postfixed with $1 \%$ osmium tetroxide in $0.1 \mathrm{M} \mathrm{PB}$ for $2 \mathrm{~h}$ at $4^{\circ} \mathrm{C}$. They were dehydrated in a graded acetone series and embedded in Epon 812. Approximately 1 $\mu \mathrm{m}$-thick sections were made on a Portor-Blum microtome and stained with methylene blue-azur II. Ultrathin sections were stained with uranyl acetate and lead citrate, and examined with a JEM 100CX electron microscope.

\section{$\left.{ }^{35} \mathrm{~S}\right]$ Methionine-labeling}

The testes were placed in Hanks' balanced salt solution (HBSS; Sigma, St. Louis, USA) and cut into small pieces (about $2 \mathrm{~mm}^{3}$ ) with a razor blade. They were incubated with $150 \mu \mathrm{ci} / \mathrm{ml}$ of $\left[{ }^{35} \mathrm{~S}\right]$ methionine (American Radiolabeled Chemicals, St. Louis, USA;

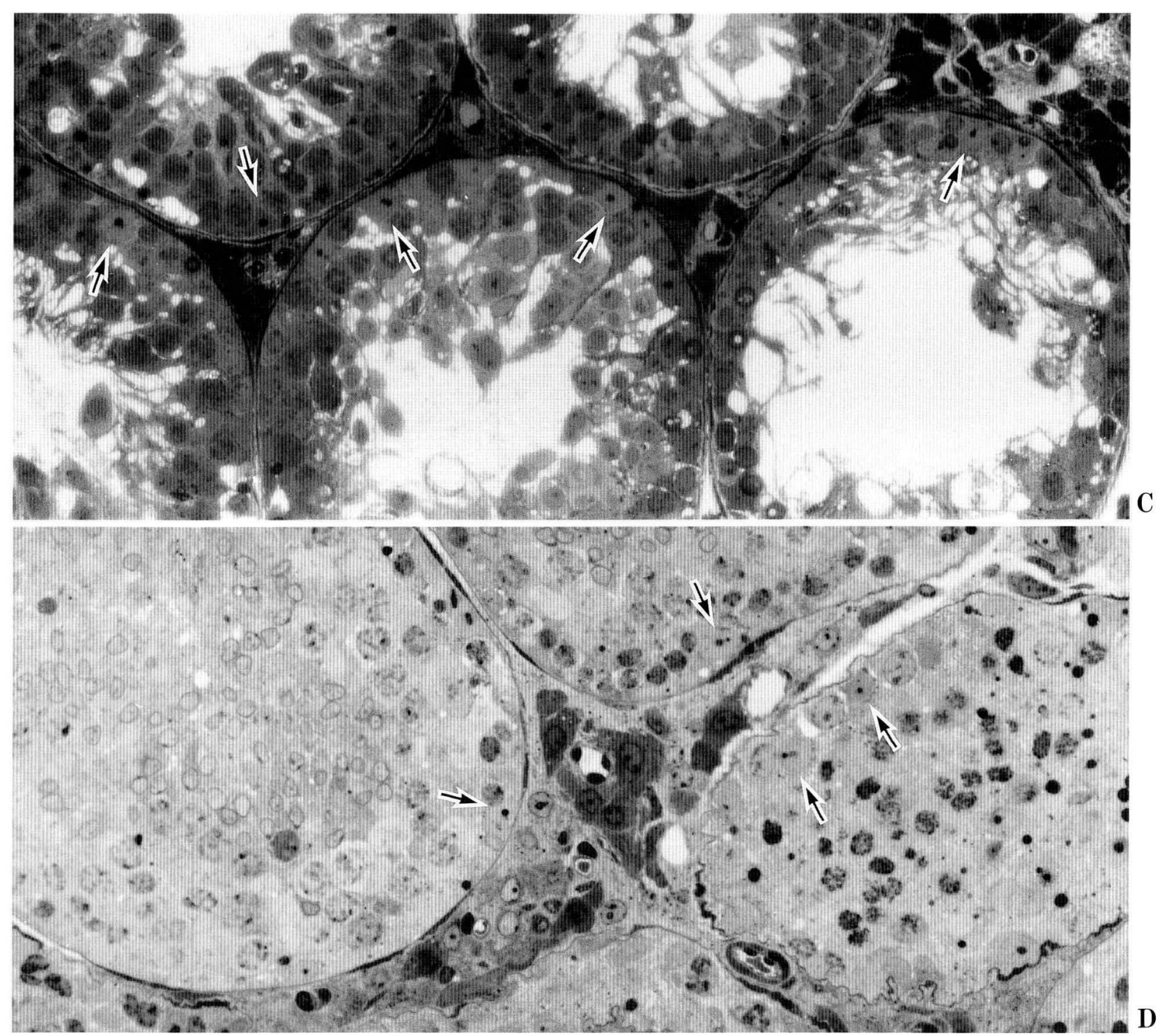



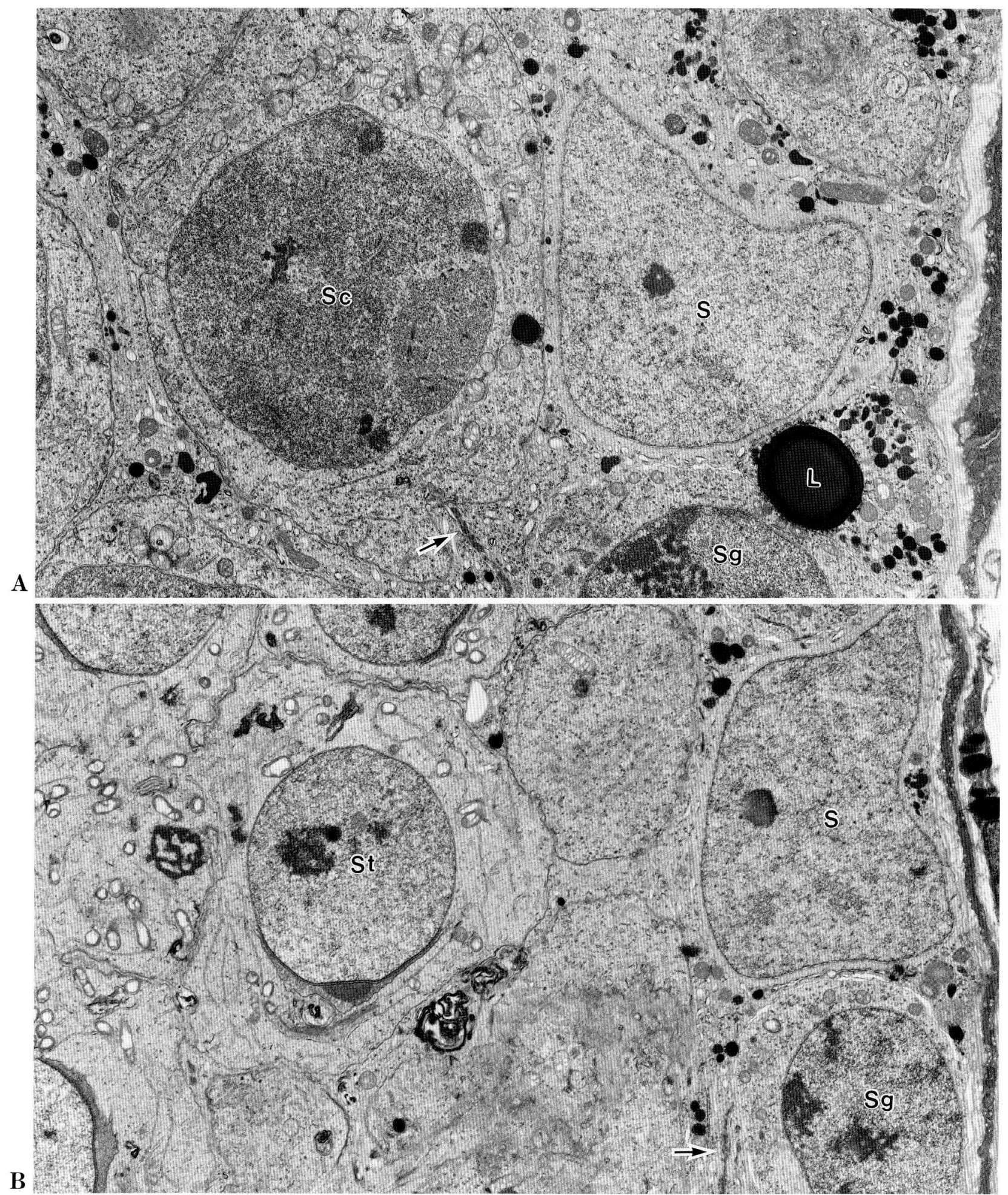

Fig. 2. Electron micrographs of Sertoli cells $(S)$ and spermatogenic cells (Sg spermatogonium, Sc spermatocyte, St spermatid) in control (A), pair-fed (B), zinc-deficient (C) and zinc replacement (D) groups. Sertoli cells and spermatogonia in the zinc-deficient group $(\mathbf{C})$ show no degenerative changes. Arrows represent Sertoli cell-Sertoli cell junctional complex. G Golgi apparatus, $L$ lipid droplet. $\times 6,000$ 


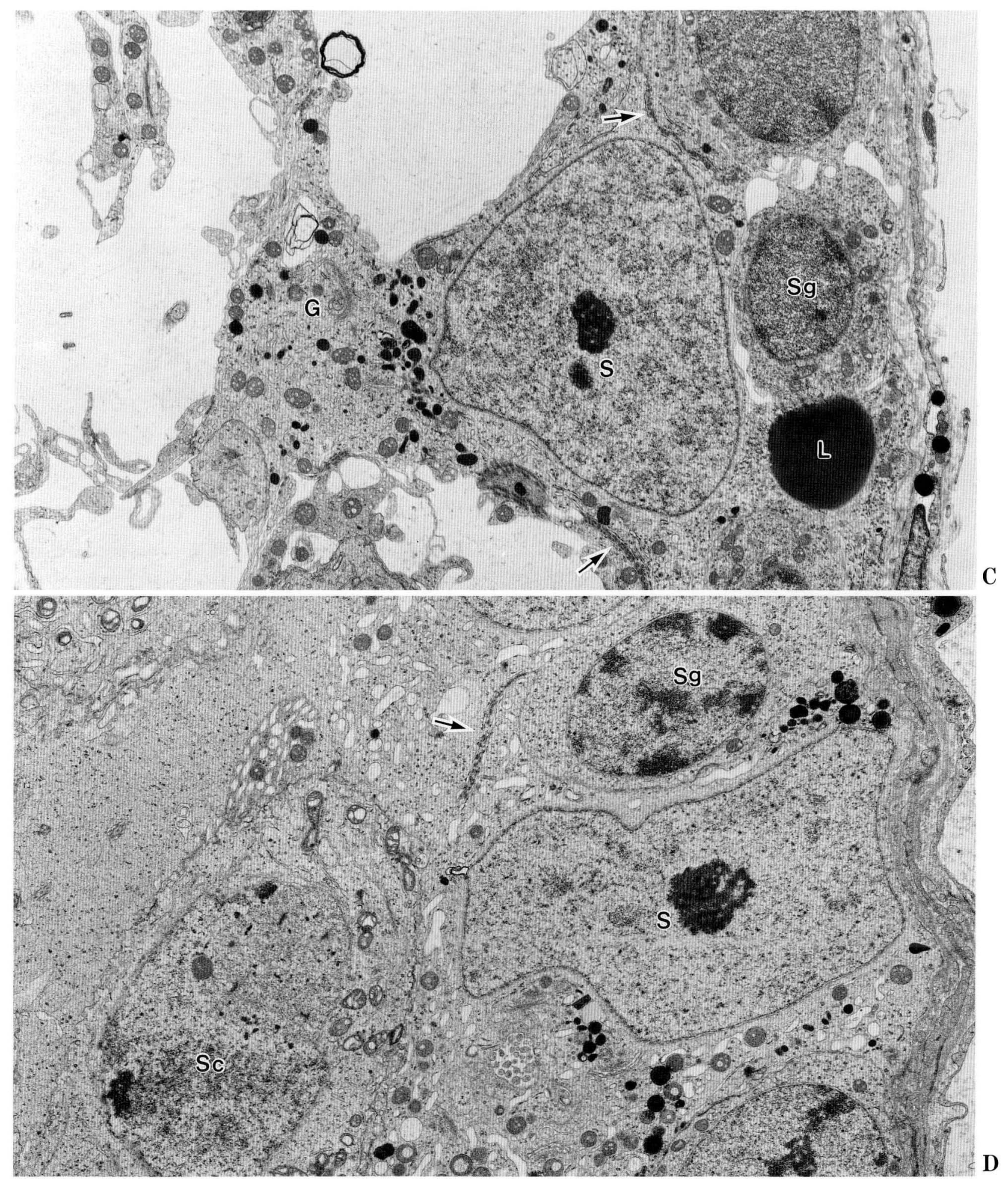


specific activity: 1,100 ci/mM) in Eagle's minimum essential medium with $10 \%$ of the normal concentration of methionine (10\% Met-MEM; Sigma) for $18 \mathrm{~h}$ at $32^{\circ} \mathrm{C}$ in a humidified atmosphere of $5 \% \mathrm{CO}_{2}$ in air. This medium was supplemented with non-essential amino acids $(0.1 \mathrm{mM})$ and antibiotics (penicillin 100 $\mathrm{u} / \mathrm{ml}$ and streptomycin $100 \mu \mathrm{g} / \mathrm{ml}$ ). After incubation, the radioactive medium was removed and centrifuged at $15,600 \mathrm{X}$ g for 5 min to remove cell debris. The resulting supernatant was frozen at $-70^{\circ} \mathrm{C}$ and lyophilized. Samples were reconstituted in $100 \mu 1$ lysis buffer (O'FARRELL, 1975). Trichloroacetic acid (TCA)-precipitable radioactivity was determined as reported previously (UEDA et al., 1988). Total protein secretion was estimated by TCA-precipitable radioactivity X $10^{4}$ per $\mathrm{mg}$ testicular protein. Samples containing 1,000,000 cpm radioactive materials were analysed by 2D-PAGE and autoradiography as has been described previously (UEDA et al., 1990).

\section{RESULTS}

Changes in GSI, DNA concentrations and total protein secretion

The effects of zinc deficiency and replacement on GSI, DNA concentrations and total protein secretion are shown in Table 1. The GSI value in the $\mathrm{ZnD}$ group was significantly lower than that in the $\mathrm{C}$ and $\mathrm{P}$ groups, while that in the $\mathrm{ZnR}$ group was slightly recovered. The DNA concentrations in the $\mathrm{ZnD}$ group were about one point five times higher than those in the $\mathrm{C}, \mathrm{P}$ and $\mathrm{ZnR}$ groups whose levels were quite similar to each other. $\left.{ }^{35} \mathrm{~S}\right]$ Methionine-labeled proteins released into the incubation medium showed no differences among the four groups.

\section{Cytological changes in seminiferous tubules}

Seminiferous tubules of the C (Fig. 1A) and P (Fig. 1B) groups revealed normal spermatogenic characteristics, and were divided into basal and adluminal compartments which contained spermatogonia and spermatogenic cells after meiosis, respectively. Zinc deficiency ( $\mathrm{nnD}$ group) caused severe atrophic changes in the adluminal compartment; some of the seminiferous tubules contained almost no spermatogenic cells after meiosis, whiles others had a few spermatocytes and spermatids in this compartment where many cytoplasmic processes of Sertoli cells were observed (Fig. 1C). However, Sertoli cells and spermatogonia in the basal compartment showed no atrophic features (Fig. 1C). In seminiferous tubules of

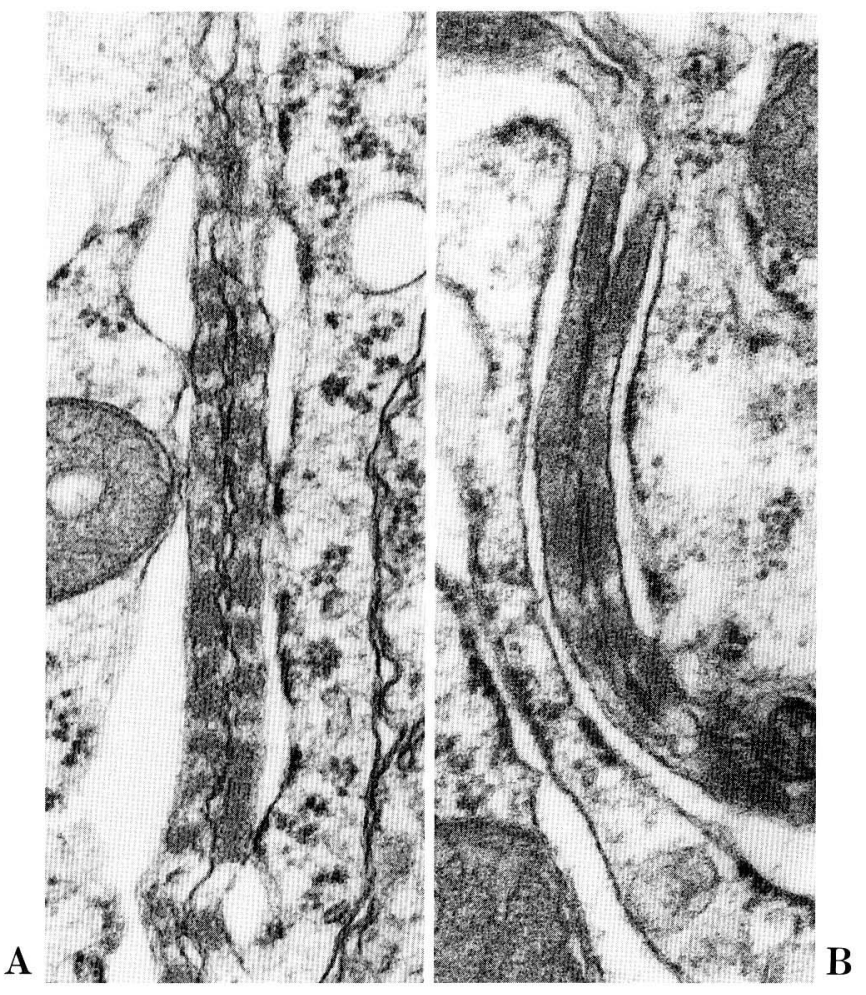

Fig. 3. Electron micrographs of junctional complexes among Sertoli cells in pair-fed (A) and zinc-deficient (B) groups. Tight junctions are observed in both groups. $\times 53,000$

the $\mathrm{ZnR}$ group, spermatogenesis recovered normally, and the adluminal compartment was filled with spermatogenic cells after meiotic division. However, no spermatozoa were observed in the zinc replacement treatment for 3 weeks (Fig. 1D). The average diameter of seminiferous tubules in the $\mathrm{C}$ and $\mathrm{P}$ groups was $250 \mu \mathrm{m}$, and that in the $\mathrm{ZnD}$ and $\mathrm{ZnR}$ groups was 130 $\mu \mathrm{m}$ and $180 \mu \mathrm{m}$, respectively.

At the fine structural level, Sertoli cells of the C (Fig. 2A) and P (Fig. 2B) groups contained a few large lipid droplets and many electron-dense granular inclusions of $200-500 \mathrm{~nm}$ in size. Junctional complexes between Sertoli cells, which mainly consisted of tight junctions, were observed between the basal and adluminal compartments (Fig. $3 \mathrm{~A}$ ). In the $\mathrm{ZnD}$ group, no degenerative changes were detected in Sertoli cells which had abundant electron-dense granular inclusions near the Golgi apparatus (Fig. 2C). Their junctional complexes still divided seminiferous tubules into two compartments, and tight junctions were well-preserved (Fig. 3B). Normal featured spermatogonia were located in the basal compartment, but the adluminal compartment contained essentially 

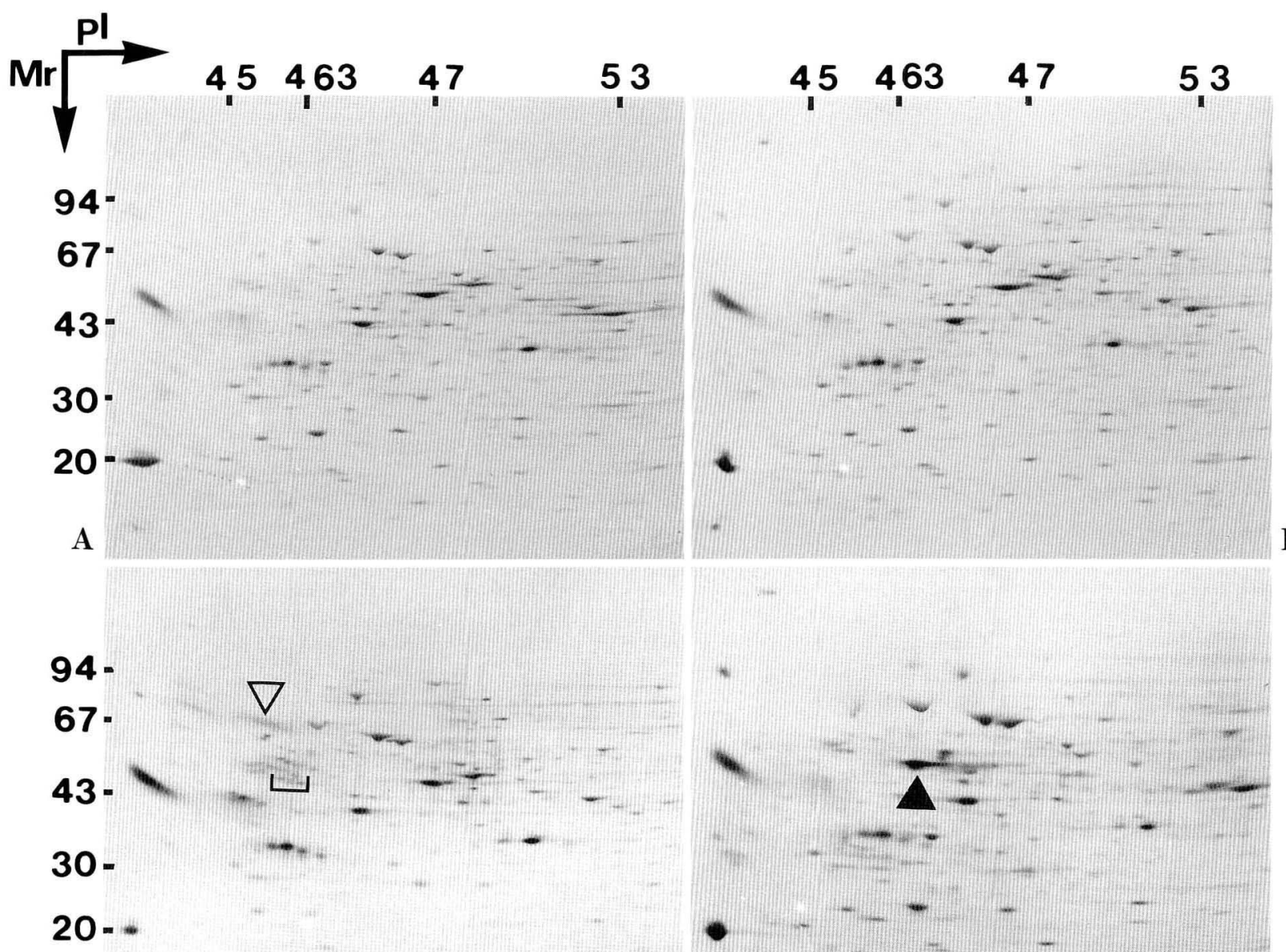

\section{C}

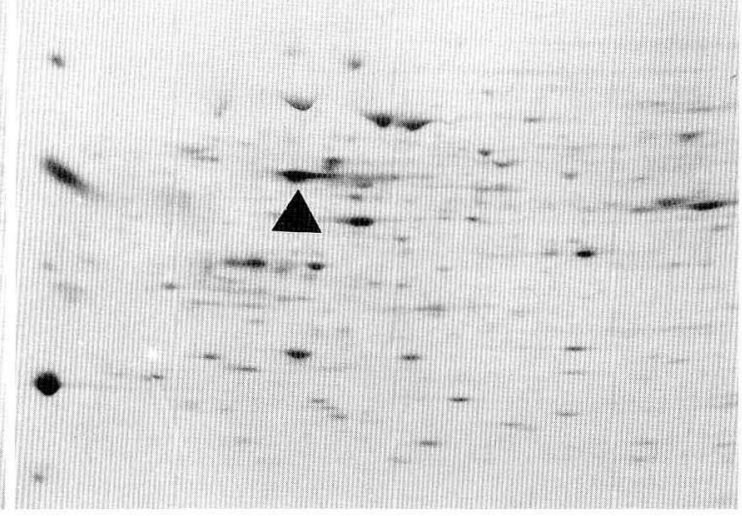

Fig. 4. Autoradiograms of radiolabeled protein $(1,000,000 \mathrm{cpm})$ accumulated in the medium of incubated testes in control (A), pair-fed (B), zinc-deficient (C) and zinc replacement (D) groups. Z70 (open arrowhead) and Z50 (brancket) appear in the zinc-deficient group (C), and Z46 (closed arrowhead) appears in the zinc replacement group (D).

few spermatogenic cells (Fig. 2C). Sertoli cells and spermatogenic cells in the ZnR group (Fig. 2D). displayed similar fine structures to those in $\mathrm{C}$ and $\mathrm{P}$ groups.

\section{Changes in protein secretory patterns}

The same amount of $\left[{ }^{35} \mathrm{~S}\right]$ methionine-labeled proteins $(1,000,000 \mathrm{cpm})$ that accumulated in the incubation medium of testes from the 4 groups were resolved by $2 \mathrm{D}$-PAGE and analyzed by autoradiography. Although the basic protein secretory patterns in the $\mathrm{C}$ (Fig. 4A), P (Fig. 4B), ZnD (Fig. 4C) and ZnR (Fig. 4D) groups were similar to each other, several minor alternations were recognized in radioactive decreases and increases of some polypeptide spots. Among these alternations, the most interesting change was the appearance of $Z 70(\mathrm{Mr} 69,000-72,000 / \mathrm{pI} 4.52-4.61$ ) in the $\mathrm{ZnD}$ group (Fig. $3 \mathrm{C}$ ). The molecular forms of Z70 were quite similar to those of S70 ( $\mathrm{Mr} \mathrm{70,000-}$ $72,000 / \mathrm{pI} 4.4-4.6)$ in rat Sertoli cell secretory proteins (ShabANowitz et al., 1986). Since S70 is considered to play important roles in the formation of acrosome and the tail of developing spermatids and spermatozoa (ABDullah et al., 1988; KiERSZENBAUm et al., 1988), it is possible that S70 in the present study appears mainly due to the loss of spermatids and spermatozoa in the adluminal compartment. The appearance of a group of polypeptides (Z50; $\mathrm{Mr}$ 48,000-56,000/pI 4.55-4.63) and Z46 (Mr 46,000/pI 4.65) 
Table 1. Effects of zinc deficiency on GSI, DNA concentrations and protein secretion in the C3H mouse

\begin{tabular}{lcccc}
\hline \multicolumn{1}{c}{ Group } & No. of mouse & GSI $^{\text {a) }}$ & DNA concentration $^{\text {b) }}$ & Protein secretion $^{\text {c) }}$ \\
\hline Control (C) & 4 & $0.72 \pm 0.06^{\mathrm{d})}$ & $4.14 \pm 0.30$ & $1.11 \pm 0.12$ \\
Pair-fed (P) & 5 & $0.71 \pm 0.07$ & $4.43 \pm 0.22$ & $1.11 \pm 0.18$ \\
Zinc-deficient (ZnD) & 5 & $0.44 \pm 0.05^{*}$ & $6.89 \pm 0.45^{*}$ & $1.31 \pm 0.27$ \\
Zinc-replacement (ZnR) & 5 & $0.56 \pm 0.04$ & $4.91 \pm 0.26$ & $1.23 \pm 0.21$
\end{tabular}

a) Testicular weight $(\mathrm{g}) \times 100 /$ body weight $(\mathrm{g})$, b) DNA $(\mu \mathrm{g}) /$ protein $(\mathrm{mg})$, $\left.{ }^{\text {c) }}{ }^{35} \mathrm{~S}\right]$ methionine $\mathrm{cpm} \times 10^{4} /$ protein (mg), ${ }^{\text {d) }}$ Values are mean $\pm \mathrm{SD},{ }^{*} \mathrm{P}<0.05$ compared with the other three groups

was also noticed in the $\mathrm{ZnD}$ group (Fig. $4 \mathrm{C}$ ) and $\mathrm{ZnR}$ group (Fig. 4D), respectively, but the functional significance of these polypeptides could not be elucidated in the present study.

\section{DISCUSSION}

The present study demonstrated severe atrophic changes from zinc deficiency in spermatogenic cells at the stages after meiosis and located in the adluminal compartment. The reduction of spermatogenic cells was associated with a significant decrease in the GSI values. A number of previous experiments have shown that zinc deficiency causes the inhibition of testicular development and abnormalities in spermiogenesis (UNDERWOOD, 1977). There is the possibility that spermatogonia, which showed no degenerative changes in the basal compartment, could survive in the absence of zinc since spermatogenesis recovered normally after zinc replacement. The zinc replacement experiments have offered controversial results among animal species. Testicular atrophy was not reversed in rats by adding zinc to the diet (MILLAR et al., 1958) but was reversible in rams (UNDERWOOD and SOMERS, 1969). This discrepancy is difficult to explain, but the mitotic activity of spermatogonia might be one possibility. Discussion continues as to whether spermatogonia are not able to preserve their mitotic activity during prolonged zinc deficiency, or zinc deficiency causes the atrophy of only spermatogenic cells after meiosis, and spermatogonia can maintain their potential proliferative activity as was the case in the present study.

The present study demonstrated a significant increase in DNA concentrations in the zinc-deficient mouse testis. MACAPINLAC et al. (1968) also found that dietary zinc deficiency for 2 weeks caused a slight but significant increase in DNA concentrations in the rat testes. In the same species given a zincdeficient diet for 10 weeks, however, the testes were reported to contain significantly lower concentrations of DNA (SOMERS and UNDERWOOD, 1969). The synthesis of DNA in the normal testis was shown to be confined to the spermatogonia and to the pre-leptotene spermatocytes (ALBERTS et al., 1983). The DNA synthesis in the latter case is the last detectable synthesis of DNA by the spermatogenic cells. In the absence of zinc, no mitotic and meiotic divisions could occur in the testis since RNA and DNA polymerization could not be accomplished. Both somatic cells and spermatogonia are diploid cells having two sets of chromosomes. On the other hand, spermatogenic cells in the adluminal compartment are mostly haploid cells containing one set of chromosomes. The increase of DNA concentrations in the absence of zinc might be related to the loss of haploid spermatogenic cells in the adluminal compartment. Nevertheless, the discrepancy of changes in DNA contents should be clarified by a time course experiment.

The junctional complexes connecting Sertoli cells are composed of tight junctions, gap junctions, septatelike junctions, desmosomes, ectoplasmic specialization and close junctions (RUSSELl and PETERSON, 1985). Among them, tight junctions are believed to function in maintaining a barrier against permeability, and are generally accepted as the blood-testis barrier. Sertoli cell tight junctions were not affected by zinc deficiency and could maintain their functional barrier. The preservation of tight junctions might be another condition for the recovery of normal spermatogenesis in zinc replacement, although more detailed cytological studies should be carried out to clarify this point.

Although it has been suggested that zinc deficiency brought about an increased protein catabolism in rat testis (MACAPINLAC et al., 1968; SOMERS and UNDER WOOD, 1969) and men (HALSTEAD et al., 1974), no 
studies have mentioned changes in testicular protein secretion. The present study indicated that zinc deficiency did not affect the total radiolabeled protein secretion from mouse testes. Thought it could not define the cellular source of testicular proteins, Sertoli cells should be the most appropriate candidate for testicular protein secretion.

The same amounts of radiolabeled proteins from the four groups were analysed by 2D-PAGE and autoradiography to detect the direct effect of zinc deficiency on testicular secretory protein patterns. The secretory patterns of the basic protein were not severely altered by zinc deficiency, but one polypeptide spot (Z70) appeared only in the zinc-deficient group. The similarities of molecular forms between Z70 and S70 in rat Sertoli cell secretory proteins lead us to consider the reason for the appearance of $Z 70$ in the zinc-deficient treatment. S70 has been found to show spermatogenic stage dependent secretory patterns by $\left.{ }^{\left[{ }^{35}\right.} \mathrm{S}\right]$ methionine labeled proteins resolved by 2D-PAGE (ShabANOWITZ et al., 1986). Moreover, S70 and the components of acrosome and the sperm tail have been reported to share antigenic homology by the immunological analysis (ABDULLAH et al., 1988; KIERSZENBAUM et al., 1988). We also found that S70 was released into both basal and adluminal compartments using a two-chamber culture system (UEDA et al., 1988). These data suggest that S70 takes part in the formation of acrosome and the tail of developing spermatids and spermatozoa which are located in the adluminal compartment. Of interest seems to be the correlation between the appearance of $Z 70$ in zincdeficient group and the loss of spermatogenic cells in the adluminal compartment. Loss of target spermatogenic cells in the adluminal compartment might bring about the appearance of $\mathrm{Z70}$ during zinc-deficient treatment.

In conclusion, the present study demonstrates the effects of zinc on spermatogenesis and the protein secretory function in the mouse testis. More detailed biochemical and cytological analyses of testicular protein secretion are now in progress in our laboratory in order to clarify the critical roles of zinc in this organ.

Acknowledgments. The authors thank Ms. Tomoko NISHINO for her technical assistance, and Ms. Toyono NOBUKUNI for typing the manuscript.

\section{REFERENCES}

Abdullah, M., L. L. Tres, H. Ueda, P. C. Hu and A. L. KiERSZENBAUM : Antigenic homology between rat sperm tail polypeptides and Sertoli cell secretory pro- teins. Mol. Cell. Biochem. 81: 165-176 (1988).

Alberts, B., D. Bray, J. Leivis, M. RAFF, K. Roberts and J. D. WATson: Molecular biology of the cell. 1st Ed. Garland Publishing, New York, 1983 (p. 769-811).

Bardin, C. W., C. Y. Cheng, N. A. Musto and G. L. Gunsalus: The Sertoli cell. In: (ed. by) E. KNOBIL and J. NeILL: The physiology of reproduction. Raven Press, New York, 1988 (p. 933-974).

Chesters, J. K.: Biochemical functions of zinc in animals. World Rev. Nutr. Diet 32: 135-154 (1978).

DinsDale, D. and R. B. Williams: Ultrastructural changes in the sperm-tail of zinc-deficient rats. J. Comp. Pathol. 90: 559-566 (1980).

Follis, R. H., H. G. DAY and E. V. McCollum: Histological studies of the tissues of rats fed a diet extremely low in zinc. J. Nutr. 22: 223-233 (1941).

Gordon, E. F., R. C. Gordon and D. B. Passal: Zinc metabolism: basic, clinical, and behavioral aspects. J. Pediat. 99: 341-349 (1981).

Halstead, J. A., J. C. Smith and M. I. Irwin: A conspectus of research on zinc requirements of man. J. Nutr. 104: 345-354 (1974).

Hesketh, J. E.: Effects of dietary zinc deficiency on Leydig cell ultrastructure in the boar. J. Comp. Pathol. 92: 239-247 (1982).

Kayama, F., K. Matsuno and Y. Kodama: Impairment of immune functions induced by zinc deficiency. Biomed. Res. Trace Elements 1: 197-198 (1990).

Kierszenbaum, A. L., M. Abdullah, H. Ueda and L. L. Tres: Spermatogenesis in vitro: searching for in vivo correlates. In: (ed. by) V. B. Mahesh, D. S. Dhindsa, E. ANDERSON and S. P. KALRA: Regulation of ovarian and testicular function. Plenum Publishing, New York, 1987 (p. 535-560).

Kierszenbaum, A. L., H. Ueda, L. Ping, M. Abdullah and L. L. Tres: Antibodies to rat Sertoli cell secretory proteins recognize antigenic sites in acrosome and tail of developing spermatids and sperm. J. Cell Sci. 91: 145153 (1988).

LaW, J. S., S. A. McBride, S. Graham, N. R. Nelson, B. M. Slotnick and R. I. HeNkin: In vivo effects of zinc deficiency on calmodulin concentrations in selected rat tissues. Life Sci. 41: 2597-2606 (1987).

LEI, K. Y., A. Abbasi and A. S. Prasad: Function of pituitary-gonadal axis in zinc-deficient rats. Amer. J. Physiol. 230: 1730-1732 (1976).

Lowry, O. H., N. J. R. Osebrough, A. L. FARR and R. J. RANDALL: Protein measurement with the folin phenol reagent. J. Biol. Chem. 193: 265-275 (1951).

Macapinlac, M. P., W. N. Pearson, G. H. Barney and W. J. DARBY: Protein and nucleic acid metabolism in the testes of zinc-deficient rats. J. Nutr. 95: 569-577 (1968).

Millar, M. J., M. I. Fischer, P. V. Elcoate and C. A. Mawson: The effects of dietary zinc deficiency on the reproductive system of male rats. Can. J. Biochem. Physiol. 36: 557-569 (1958).

Miller, W. J., W. J. Pitts, C. M. Clifton and S. C. SchmitTLE: Experimentally produced zinc deficiency 
in the goat. J. Dairy Sci. 47: 556-559 (1964).

O'Farrell, P. H.: High resolution two-dimensional gel electrophoresis of proteins. J. Biol. Chem. 250: 40074021 (1975).

Orgebin-Crist, M. C., M. Freeman and G. H. Barney: Sperm formation in zinc-deficient rats. Ann. Biol. Anim. Biochim. Biophys. 11: 547-558 (1971).

Pitts, W. J., W. J. Miller, O. T. Fosgate, J. D. Morton and C. M. Clifton: Effect of zinc deficiency and restricted feeding from two to five months of age on reproduction in Holstein bulls. J. Dairy Sci. 49: 995-1000 (1966).

Prasad, A. S. and D. Oberleas: Thymidine kinase activity and incorporation of thymidine into DNA in zincdeficient tissue. J. Lab. Clin. Med. 83: 634-639 (1974).

Prasad, A. S., D. Oberleas, P. Wolf and J. P. Horwitz: Studies on zinc deficiency: changes in trace elements and enzyme activities in tissues of zinc deficient rats. J. Clin. Invest. 46: 549-557 (1967).

Russell, L. D. and R. N. Peterson: Sertoli cell junctions: morphological and functional correlates. Int. Rev. Cytol. 94: 177-211 (1985).

SchNeIDER, W. C.: Determination of nucleic acids in tissues by pentose analysis. In: (ed. by) S. P. Colowick and N. O. Kaplan: Methods of enzymology. Vol. 3. Academic Press, New York, 1957 (p. 680-684).

Shabanowitz, R. B., R. M. DePhilip, J. A. Crowell, L. L. Tres and A. L. KierszenbaU M: Temporal appearance and cyclic behavior of Sertoli cell-specific secretory proteins during the development of the rat seminiferous tubule. Biol. Reprod. 35: 745-760 (1986).
Somers, M. and E. J. Underwood: Ribonuclease activity and nucleic acid and protein metabolism in the testes of zinc-deficient rats. Aust. J. Biol. Sci. 22: 12771282 (1969).

Ueda, H., L. L. Tres and A. L. Kierszenbaum: Culture patterns and sorting of rat Sertoli cell secretory proteins. J. Cell. Sci. 89: 175-188 (1988).

Ueda, H., T. Hirano and S. Fujimoto: Changes in protein secretory patterns during the development of the rat epididymis. Zool. Sci. 7: 681-690 (1990).

UNDERWOOD, E. J.: Trace elements in human and animal nutrition. 4th Ed. Academic Press, New York, 1977 (p. $1-130)$.

Underwood, E. J. and M. Somers: Studies of zinc nutrition in sheep. I. The relation of zinc to growth, testicular development and spermatogenesis in young rams. Aust. J. Agr. Res. 20: 889-897 (1969).

Dr. Hiroshi UEDA

Toya Lake Station for Environmental Biology Faculty of Fisheries

Hokkaido University

Abuta, Hokkaido

049-57 Japan

上田宏

049-57 北海道虬田郡虬田町字月浦

北海道大学水産学部付属

洞爺湖実験所 